\title{
ハイブリッド 合成法に用いる統計的グリーン関数法の長周期帯域への拡張
}

\author{
香川敬生 ${ }^{1)}$ \\ 1) 正会員 (財)地域地盤環境研究所, 主席研究員 理博 \\ e- nai l: kagana@eor. or.jp
}

\begin{abstract}
要 約
ハイブリッド合成法による強震動予測に際して短周期地震動の計算に用いられる, 統計的グリー ン関数法 (短周期帯域) をより長周期帯域に適用できるように拡張した。ハイブリッド合成法で は, 観測地震動力確定量から統計量に推移する周期帯において, 確定的に評価される長周期地震 動と統計的な表現による短周期地震動を合成することか理想である。しかし，確定的手法でモデ ル化できる構造変化の波長 (計算周期に影響) に限界があることなどから，実際の現象よりも長 周期帯域でハイブリッド合成されていることが多い。本研究では, 統計的グリーン関数法に長周 期帯域でコヒーレントな震源時間関数を導入することで, 適用範囲の長周期化を図っている。ま た，周波数依存型放射特性 , 水平成層地盤構造による理論応答を導入することにより手法の高度 化をおこなっている。このため, 露頭岩盤あるいは水平成層地盤構造を仮定できる震源近傍域に ついは, 実用される広い周期帯域において, 統計的グリーン関数法のみで合理的な地震動評価 か河能となっている。
\end{abstract}

キーワード： 統計的グリーン関数法, ハイブリッド合成法, 離散化波数法, 地震動

1. はじめに

広周期帯域の地震動をひとつの手法によって合理的に評価することか困難であるため，現状では長周期成分 に利点を持つ手法と短周期成分に有利な手法を組み合わせたハイブリッド合成法 [Kamæe et al . (1998) ${ }^{1}$ ] 用いられることが多い。長周期成分の計算には確定モデルに基づく離散化波数法 [Bouchon( 1981) $\left.{ }^{2}\right]$ や差分法 $\left[\right.$ G a a es $\left.(1996){ }^{3)}\right]$ の理論計算手法が用いられている。一方 , 短周期成分の計算には震源スペクトルに基ついた 統計的波形[ Boor e( 1983) $\left.{ }^{4}\right]$ を要素地震波とした統計的グリーン関数法 [ 釜江・他 (1990) $\left.{ }^{5}\right]$ が一般的である。 ハイブリッド合成法における 2 手法の遷移周期帯は，観測地震動か確定量から統計量に推移する周期帯と一 致していることが，光れ光れの手法の特性から理想である [Nat sushi ma and Sat o( 2002) ${ }^{\circ}$ ]。しかし, 確定的 手法ではモデル化の精度と計算量の関係から，扱うことのできる波長 (周期) に限界がある。このため, 一 般には実際の現象よりも長周期帯域でハイブリッド合成か実施されている。これを避けるためには，確定的 手法による長周期帯域の計算範囲をより短周期側に伸ばすアプローチと，統計的手法による短周期帯域の計 算をより長周期側に拡張するアプローチが考えられる。

本研究では,このうち後者の立場から統計的グリーン関数法の適用周期帯の長周期化を図り，ハイブリッド 合成法の高精度化を試みるものである。具体的には，長周期帯域で震源理論通りの波形を生成するために， SH波，SV波およびP波の放射特性を与えた 3 成分の統計的グリーン関数を，対象断層を分割した要素断層で 


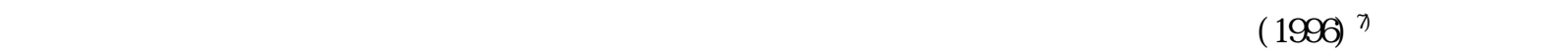
(2000) ${ }^{8)}$ て利用されている。さらに, 釜江・他(1990) ${ }^{5}$ が Nont e Carl o 法によって導いた放射特性の周波数依 存性を，香川・江尻( 1998) ${ }^{9}$ やPul i d(2001) ${ }^{10)}$ ではモデル化して計算の合理化を図っている。しかし，これら の手法で用いられる統計的グリーン関数では乱数位相を用いており，理論的にはコヒーレントな゙波形か期待 される長周期帯域においてさえ震源時間関数の位相がランダムとなっている。

本論では,長周期の変位波形が常に正方向でコヒーレントであり, 理論的に求められる波形と同じ特徵を持 った震源時間関数を生成し, 光れによって統計的手法のみて短周期側の統計的性質と長周期側の確定的でコ ヒーレントな性質を併せ持つ地震波形のシミュレーション法を提案する。このことにより，統計的グリーン 関数法の適用周期帯をより長周期にまで拡張することができ, 理論波形とのハイブリッド合成を合理的かつ 精度良く実施できることか期待される。

\section{2 統計的グリーン関数法の高精度化}

本研究て提案する統計的グリーン関数法の計算手法について , ステップを追って述べる。

\section{1 震源における統計的グリーン関数の生成}

最初に対象震源断層を分割した要素断層から発生する小地震波形 (単位震源距離) を, ( 1)式のスペクトル $S_{A}(f)$ を満たすように統計的波形として生成する ${ }^{4)}$ 。

$$
S_{A}(f)=R_{\theta \phi} \frac{\pi M_{0}}{\rho V^{3}} \frac{f^{2}}{1+\left(f / f_{c}\right)^{2}}
$$

式(1)中， $M$ はは地震モーメント， $\rho$ は媒質 (地震発生層) の密度である。なお, 式(1)の小地震波形はP $\mathrm{P}$ 波 およびS波 (SH波，SV 波) に対して乥れ光れ独立に生成し，式中のVは光れ光れの地震波速度に対応する。 また， $f_{c}$ は応力降下量と連動して設定されるコーナー周波数 ${ }^{11}$ を示す。なお , 式( 1) の $R_{\theta}$ はラディエーショ ン係数であり, 要素断層毎に導入される。ここで,ラディエーション係数には釜江・他( 1990) ${ }^{5}$ が Mont e Carl 0 法で検討した周波数依存性を式( 2)のようにモデル化して導入し, 計算の高速化を図る。Pul i d( 2001) ${ }^{10)}$ でも 同樣の考え方を用いたモデル化がおこなわれている。

$$
R_{\theta \phi}(f)=\frac{\left(\log \left(f_{2}\right)-\log (f)\right) R_{\theta \phi 0}+\left(\log (f)-\log \left(f_{1}\right)\right) R_{\theta \phi m}}{\log \left(f_{2}\right)-\log \left(f_{1}\right)}
$$

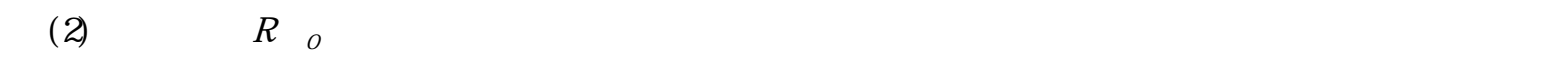
ン係数 ${ }^{12}$ を, $R_{\theta \varphi n}$ は高周波数で等方放射として平均化されたラディエーション係数 ${ }^{13}$ を示している。パラメ ター $f_{1}, f_{2}$ は理論的な放射から等方的な放射へと遷移する周波数帯を示し 釜江・他( 1990) ${ }^{5}$ に倣って $f_{1}=0.5 \mathrm{H}$ ，

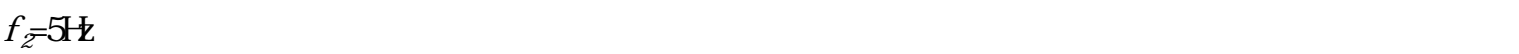

式(1)のスペクトルを満たす波形を生成するためには位相情報が必要となるが，一般には乱数列に Boor e (1983) ${ }^{4}$ による波形包絡形を施したものが用いられ，(1)式のスペクトルへの適合度と波形包絡形への適 合度を同時に向上するように繰り返しフィッティングがおこなわれている。しかし，これだけでは確定論的 に取り扱うことが可能な長周期帯域においてさえ震源時間関数の位相がランダムとなり，理論的にはコヒー レントな゙波形か期待されつつも，用いる乱数セットによっで波形の形状か安定しない。図 1 には, 一般に用 いられる乱数位相で生成した統計的グリーン関数の例を示す。図の左に乱数セットを取り替えた 10 波の加速 
度, 速度, 変位波形を, 最下段に最大振幅の平均値と標準偏差およひ変動係数を示している。加速度度, 速 度, 変位とも, 最大值の変動係数は約 $20 \%$ となっている。図の右側は 10 波のフーリエ速度振幅・位相スペク トルの平均と標準偏差を示し, 最下段に振幅の対数標準偏差 (実線) および位相の標準偏差を位相角 90 度で 正規化したもの (破線) の周波数特性を示している。振幅スペクトルおよび加速度波形の包絡形状は安定し ているものの，変位波形の形状は大きくばらつき，位相が逆転しているものも見られる。これを反映して， 低周波数における位相のばらつきは高周波数と変わらず約 90 度の標準偏差となっている。長周期带域を理論 的方法に置き換えるハイブリッド法を適用するとはいえ，遷移周期帯が長周期側になる場合には，SH波と SV 波など異なる波動間の干渉を必ずしも適切に表現しない波形が選択される危険性がある。
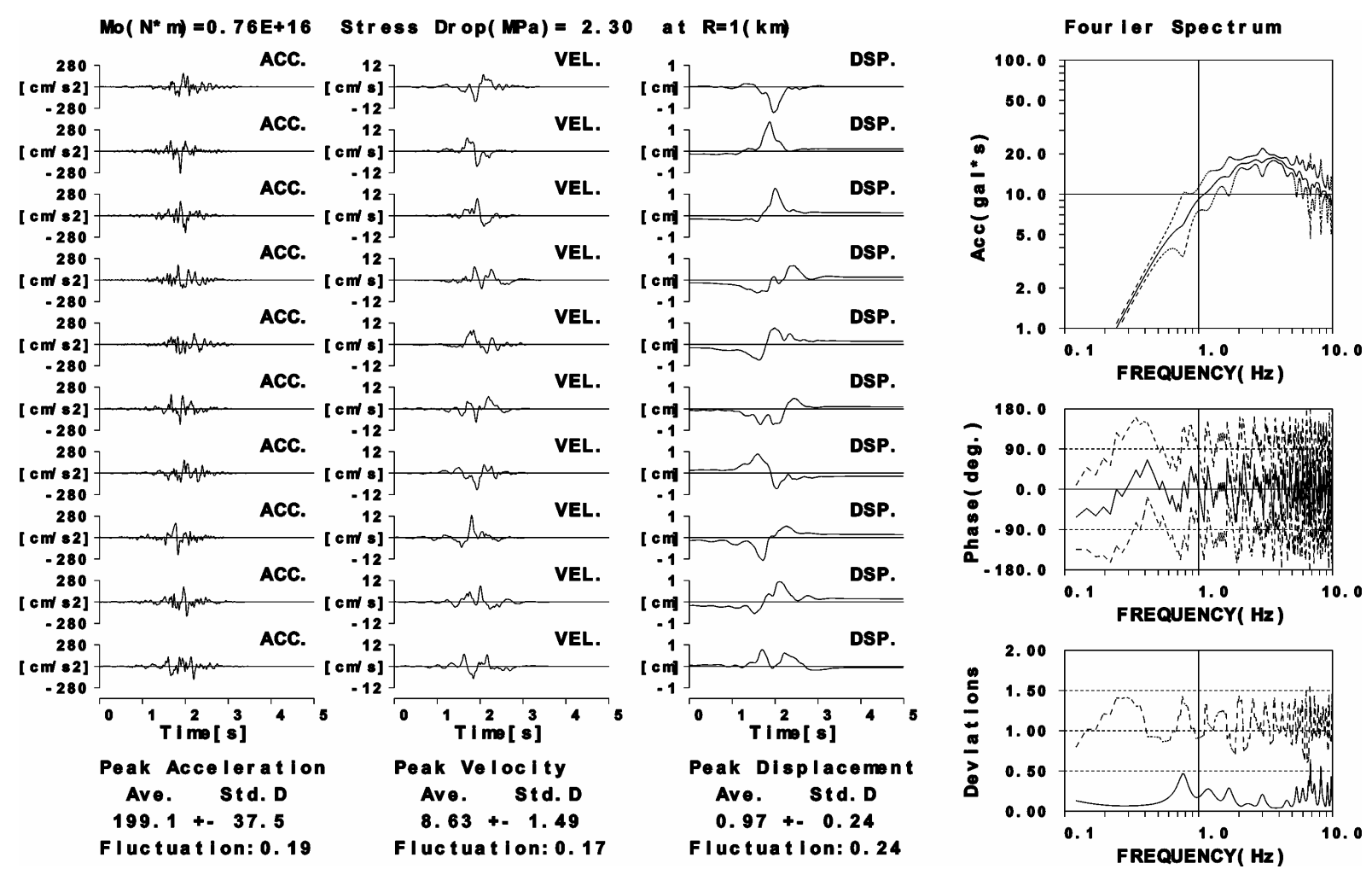

図1＼cjkstart従来手法による乱数時系列の異なる統計波の生成例

この危険性を回避するため, 以下の手順により長周期 (变位波形) でコヒーレントな統計的グリーン関数 を生成する。

1)一般的な方法と同樣に, ターゲット・スペクトルへの適合度と波形包絡形への適合度を同時に満たす統 計的波形を生成する。ホワイト・ノイズに包絡形を掛けた波形をフーリエ変換し，兴の後強制的にタ 一ゲット・スペクトル形状に合わせて逆変換した上で包絡形前後のリップルを取り除く，という操作 を繰り返す。

2) コーナー周波数 $\left(f_{c}\right)$ よりも高周波数の成分をハイカット・フィルターで落とし, 積分して変位波形を 作成する。ここでの例では，0.5 $f_{c} \sim f_{c}$ の周波数帯で低減するフィルターを用いている。ここでの事例 では, $f_{c}=1.15 \nvdash$ となっている。

3）変位波形が最大值を示す時刻が, 設定值から期待される時刻から大きく外れるものを棄却する。ここで は, 設定値の前後 0.2 秒を閾值とした。 
4) 变位波形の最大值 ( $D_{\text {nax }}$ : 正の值) と最小值 ( $D_{\min }$ : 負の值) について, 以下の条件を満たさないものを 棄却する。

$$
1-\varepsilon<\frac{D_{\max }}{D_{\max }-D_{\min }}<1+\varepsilon
$$

ここでは, $\epsilon=0.2$ とした。このことにより正の方向にべル型の形状を持つ変位波形のみか採用される ことになる。

図 2 に,このようにして生成した乱数セットの異なる 10 波を示す。構成は図 1 と同樣である。図からは， 乱数時系列によらず長周期 (変位波形) でコヒーレントかつ短周期 (加速度波形) でランダムな性質を持っ た統計波を生成することができていることが分かる。特に，変位波形はすべて同じ方向にピークを持ってい る。このため，コーナー周波数（ここでの設定は 1 15ト飞）より高周波数における位相のばらつきは図 1 と同 樣であるが, 弚れよりも低周波数ではばらつきが小さくなっていることが分かる。位相のばらつきを示す右 下図の破線にパルス状に大きなピークが見えるのは，位相がちょうどひと回りしたことによる影響であり， 実際に大きくばらついているわけではないことか位相スペクトル図から読みとれる。また , 波形の継続時間 はコーナー周波数に見合ったものとなっている。
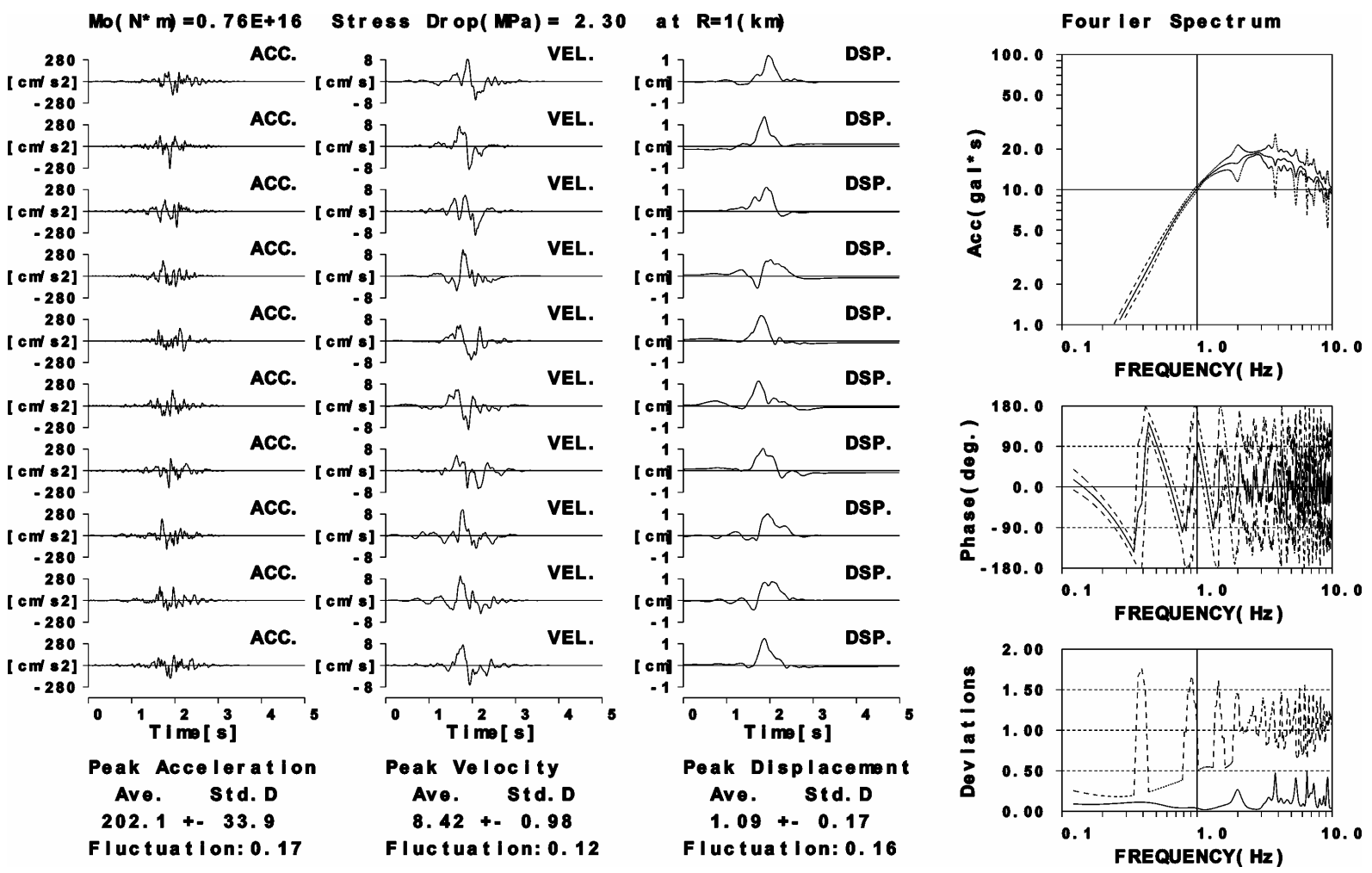

図 2 提案手法による乱数時系列の異なる統計波の生成例

このような波形をP 波, SH波およびSV波に対して独立した乱数時系列から生成することにより，長周期帯 域では理論通りの振動方向が卓越し，短周期帯域ではランダムな振動となる合理的な要素地震動（統計的グ リーン関数)を生成することができる。従来の方法では，SH波と SV波の位相か伓用意に干渉することにより， 望まない形状，振幅の合成波となることが色惧される。 


\section{2 伝播経路特性とサイト 増幅特性の導入}

単位距離で生成された要素地震波は，一樣と仮定した媒質 (地震発生層) 内を伝播してサイト下の地震基 盤に至る。震源点からサイトまでの伝播経路は地震発生層を含む全体を水平成層構造とした地款・地盤モデ ル内の波線追跡 ( P 波と S波は独立に扱う) によって評価され，表層への入射位置・入射角・震源点からの 射出角力要素断層毎に設定される。光れよりも表層は水平成層地盤としてモデル化し，応答は入射角を考慮 した Haskell Natri ${ }^{14)}$ にっって評価する。产の際，SH波入射に際してはSH波動場 (Transver se 成分)，P波 および SV 波入射に際してはP - SV 波動場 (Radi al 成分) を仮定した計算を実施する。大西・堀家 (2000) ${ }^{8}$ で は，媒質に深さ依存性を与え波線追跡法によって地表までの波動伝播を表現している。また，内部減衰は， 伝播経路としての地震発生層および水平成層地盤内とも，周波数依存を考慮した Q值を介して設定する。計 算した地表面波形はNS，EW，UDの3 成分に射影された上て断層面上の重ね合わせを実施する。

表層応答は要素断層毎に入射角を変えて評価されるため, 基盤で大地震を合成した後に表層地盤への鉛直 入射て堆積層構造の影響を評価する場合よりも合理的である。ただし，非線形応答を考慮すべき地盤では， 小振幅の要素地震毎には線形地盤応答を仮定して地表面地震動を一旦合成し, 非線形忍答を考慮する必要が 無し深さまで光れを線形計算で戻した上で, 再度地表に向けて非線形応答計算をおこなう, など別途評価が 必要である。

\section{3 グリーン関数の重ね合わせ}

対象断層を分割した要素断層の光れぞれに対して計算した要素地震動をグリーン関数として , 入倉・他 (1997) ${ }^{15}$ による合成法を用いて断層破壊の進展に応じて重ね合わせる。入倉・他 (1997 ${ }^{15}{ }^{15}$ は I r i kur a( 1986) ${ }^{16}$ によって提案された $\omega^{-2}$ 則に従ったグリーン関数合成法で, 想定大地震と要素小地震のコーナー周波数の差が 大きい場合 (地震規模が大きく異なる場合) に，両コーナー周波数間で合成波のスペクトルか㳅安定となる 現象を改善したものである。式(4)，(5)に入倉・他( 1997) ${ }^{15}$ の合成法を式で示す。なお，計算にあたって周波 数依存型ラディエーション係数や Haskell Natrix など周波数領域の計算法を導入していること，また計算ア ルゴリズムの高速化の観点から，ここでは周波数領域による表現を用いている。また，提案する統計的グリ

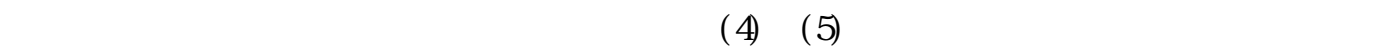

$$
\begin{aligned}
& U(\omega)=\sum_{m=1}^{N L} \sum_{n=1}^{N W} \frac{1}{r_{m n}} e^{-i \omega t_{m n}} \\
& \left\{1+\frac{1}{n^{\prime}\left(1-e^{-1}\right)} \sum_{k=1}^{(N D-1) n^{\prime}} e^{-\frac{k-1}{(N D-1) n^{\prime}}} e^{-i \omega \frac{(k-1) \tau}{(N D-1) n^{\prime}}}\right\} \cdot u_{m n}(\omega) \\
& t_{m n}=\frac{r_{m n}}{V_{s}}+\frac{\xi_{m n}}{V_{R}}
\end{aligned}
$$

式中， $\psi(\omega)$ は対象とする大地震のフーリエ・スペクトルであり， $u_{n m}(\omega)$ は各要素地震波のフーリエ・ス ペクトルを示している。図3にも示される $t_{n m}, r_{n m} \xi_{n m}$ は, 小断層に起因する要素地震波か破壊開始時刻か らサイトに到達するまでの時間, 要素小断層の重心からサイトまでの距離, 破壞開始点から要素小断層の重 心までの距離，を谷れ示している。V、破壞伝播速度である。また，ある要素小断層における断層すべり の継続時間（立ち上がり時間 : Ri se ti n巴) をTで表している。

ここでは, 対象とする大地震の断層面を走向方向に $N$ 個, 幅方向に $N$ 個, すべりの成長方向に $N$ 個と分 割している。式(4)中の $n^{\prime}$ はI ri kura (1986) ${ }^{10}$ によって導入されたものであり , 要素断層の大きさによって 
生じる特徵的な周期の応答を抑えるとともに , 再分割数後の重ね合わせ周期を地震動の離散化周期 (サンプ

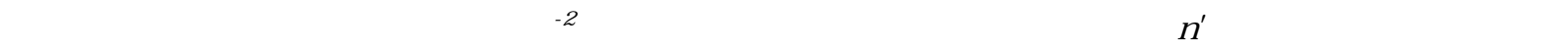
い場合, 高周波数の合成振幅力㴗素地震の振幅の $N^{15}$ となり， $\omega^{-2}$ 則による $N(N=N, N W N$ 均りも過大評 価されてしまう。なお, 合成にあたって要素断層毎にすべり量の大きさや立ち上がり時間を変えた非一樣す ベりモデルも，この段階で容易に導入することができる。

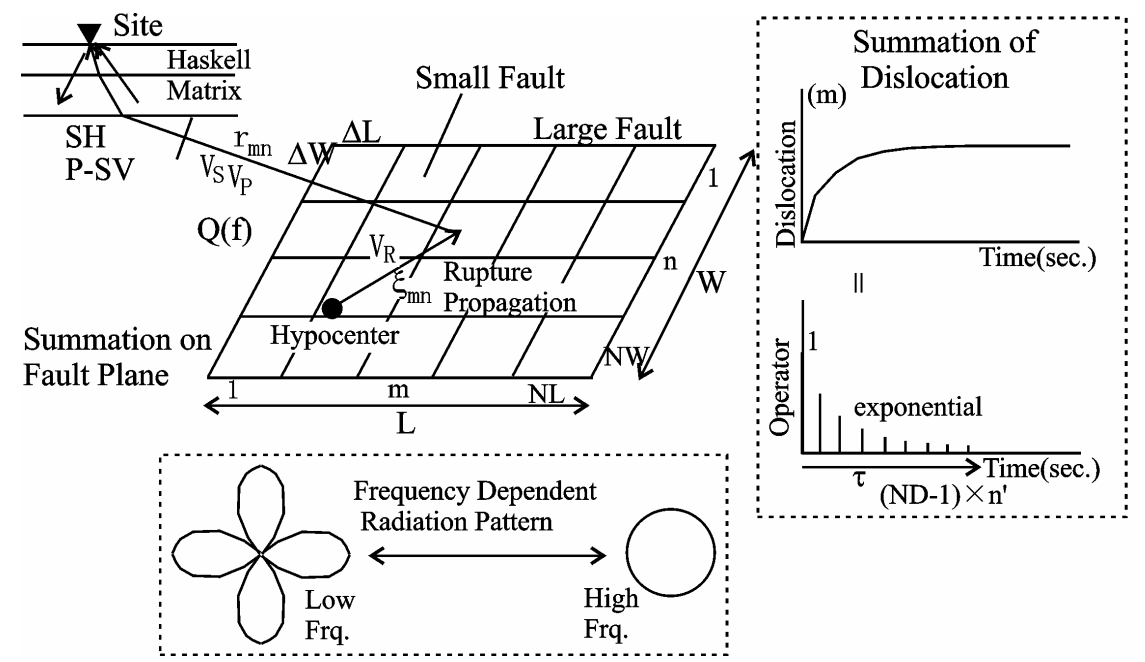

図 3 提案する統計的グリーン関数合成法の模式図

\section{3. 震源近傍強震動の試算}

上記の統計的グリーン関数法を用いて断層震源による震源近傍域の強震動を試算する。
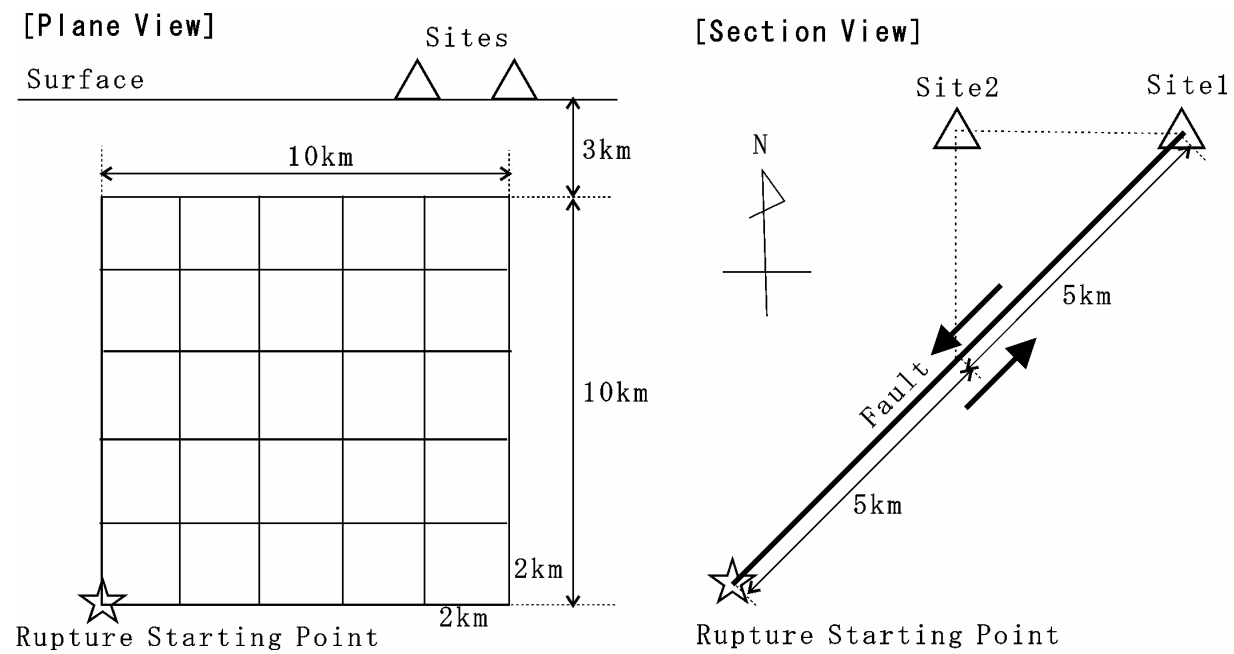

図 4 試算に用いる断層破壊モデルとサイトの位置

図 4 に設定した震源とサイトの位置関係を示す。震源は純粋な左横ずれ断層とし，鉛直傾斜とした。断層 面積から Somervill le et al. ( 1999) ${ }^{17}$ によって想定される地震モーメントは $9.5 \times 10^{17} \mathrm{~N} \mathrm{~m}$ (MW5. 9) , 平均応力 
降下量は 2.3MPa，立ち上がり時間は 0.43 秒となる。I ri kura ( 1986) ${ }^{10}$ に従って波形合成をおこなう要素地震 の規模が , 図 1，2に示した統計的グリーン関数に相当する。すべりは, アスペリティを設定せずに一樣と した。表1には,計算に用いた地盤構造モデルを示す。震源から放射される地震動の差異に着目したいため， 特に堆積層を考慮せず，地震基盤に堆積盆地などで一般に想定される岩盤を載せた 2 層構造モデルとした。

表1＼cjkstart試算に用いる構造モデル

\begin{tabular}{|c|c|c|c|c|c|}
\hline $\operatorname{depth}(\mathrm{km})$ & $V_{\mathrm{p}}(\mathrm{km} / \mathrm{s})$ & $V_{\mathrm{S}}(\mathrm{km} / \mathrm{s})$ & $\rho\left(\mathrm{tf} / \mathrm{m}^{3}\right)$ & $Q_{\mathrm{S}}$ & $Q_{\mathrm{P}}$ \\
\hline $0.0 \sim 1.0$ & 5.0 & 3.0 & 2.7 & 200 & 400 \\
\hline $1.0 \sim$ & 6.0 & 3.5 & 2.8 & 250 & 500 \\
\hline
\end{tabular}
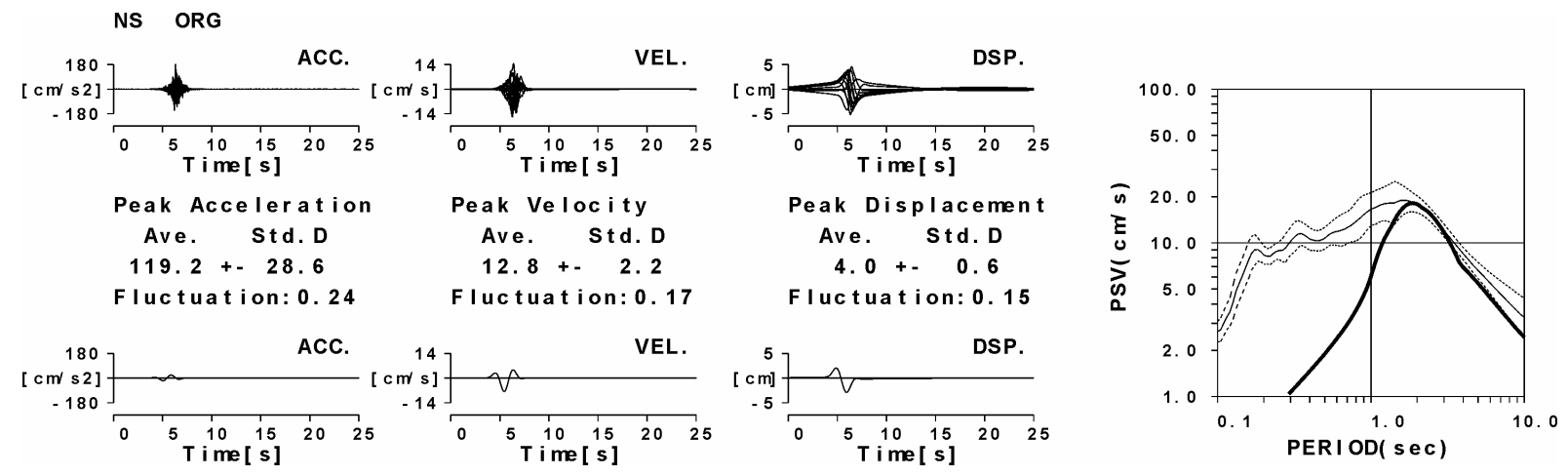

図 5(1) サイト1における計算結果 (従来手法)
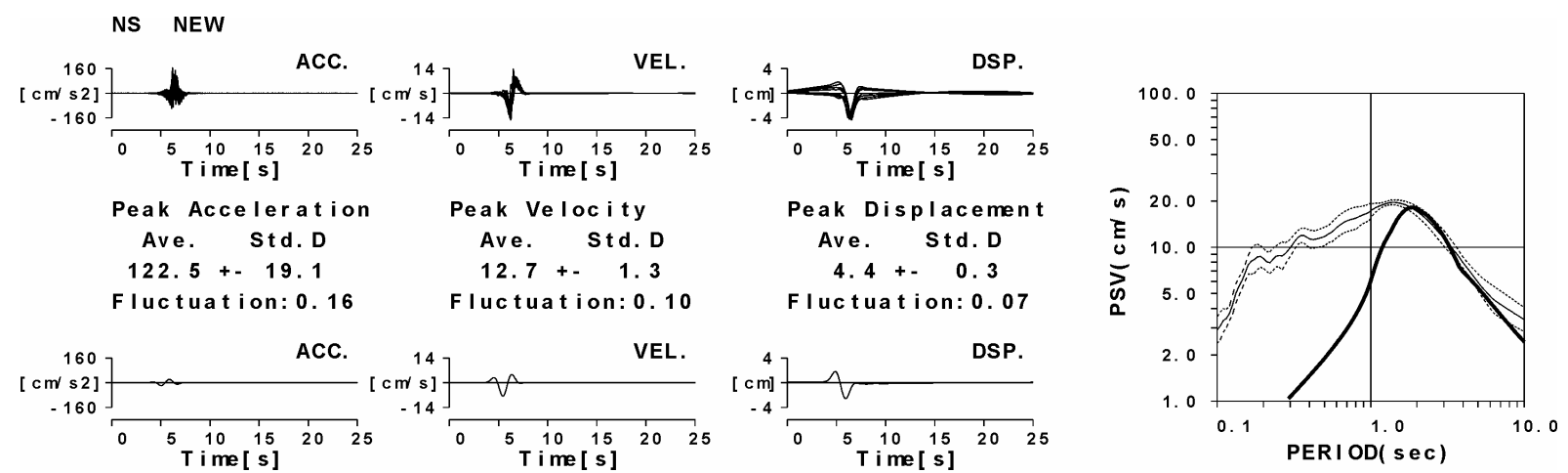

図5(2) サイト1における計算結果（提案手法）

従来手法と提案手法て計算したサイト 1におけるNS成分の計算結果を図 5(1)および図 5(2) に示す。ここ では, 理論との比較のため周波数依存型の放射特性を導入してはいない。図の上段の波形が, 乱数の組み合 わせを変えた要素波を採用した 10 通りの計算結果を重ね書いたものである。下段の波形は離散化波数法 ${ }^{2} に$ よって計算した理論波形である。従来手法による変位波形では位相が逆転したものを含めばらつきが大きく なっており, 最大振幅の変動係数も15\%程度となっている。一方, 提案手法では変位波形だけではなく速度波 形の位相もほほ揃い, 速度・変位の最大振幅の変動係数が10程度以下と小さくなっている。右側には各計算 波形による疑似速度応答スペクトルの平均 (実線) およひ対数標準偏差の幅 (破線) を示す。太線は離散化

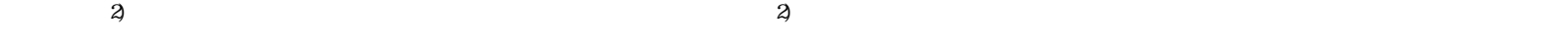


したもの (遷移帯は周期 1〜2秒) を用いている。長周期のスペクトルは, 両手法とも理論波形のスペクトル と良く対応していることがわかる。しかし，従来手法では長周期波形の位相が逆転する組み合わせがあり， 例えば断層セグメント毎，またアスペリティ毎に異なる統計的グリーン関数を組み合わせて用いるような場 合に , 波の干渉によっては長周期成分を過小評価する可能性が色惧される。ただし，これをハイブリッド法 によって回避することは可能である。
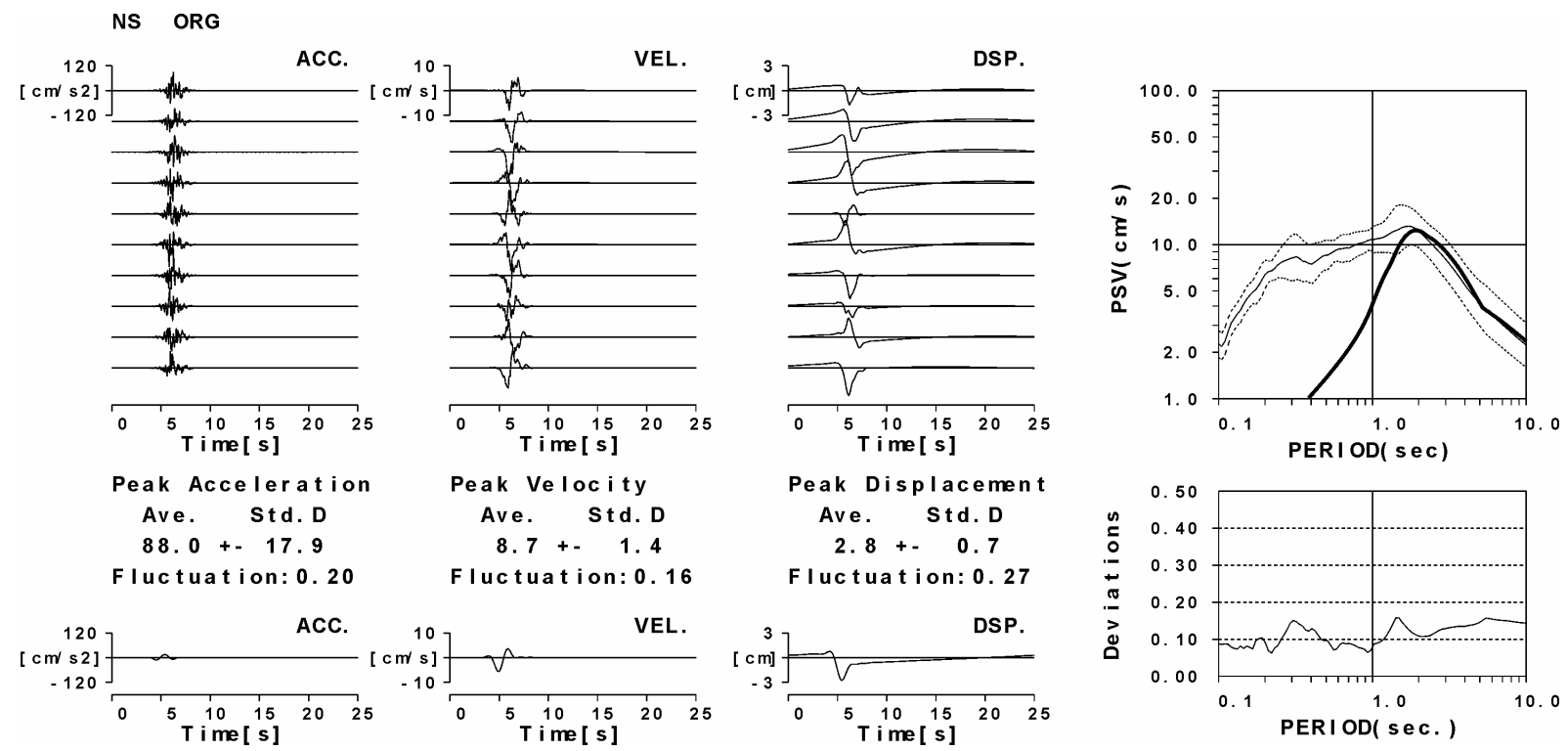

図6(1) サイト2における計算結果 (従来手法)
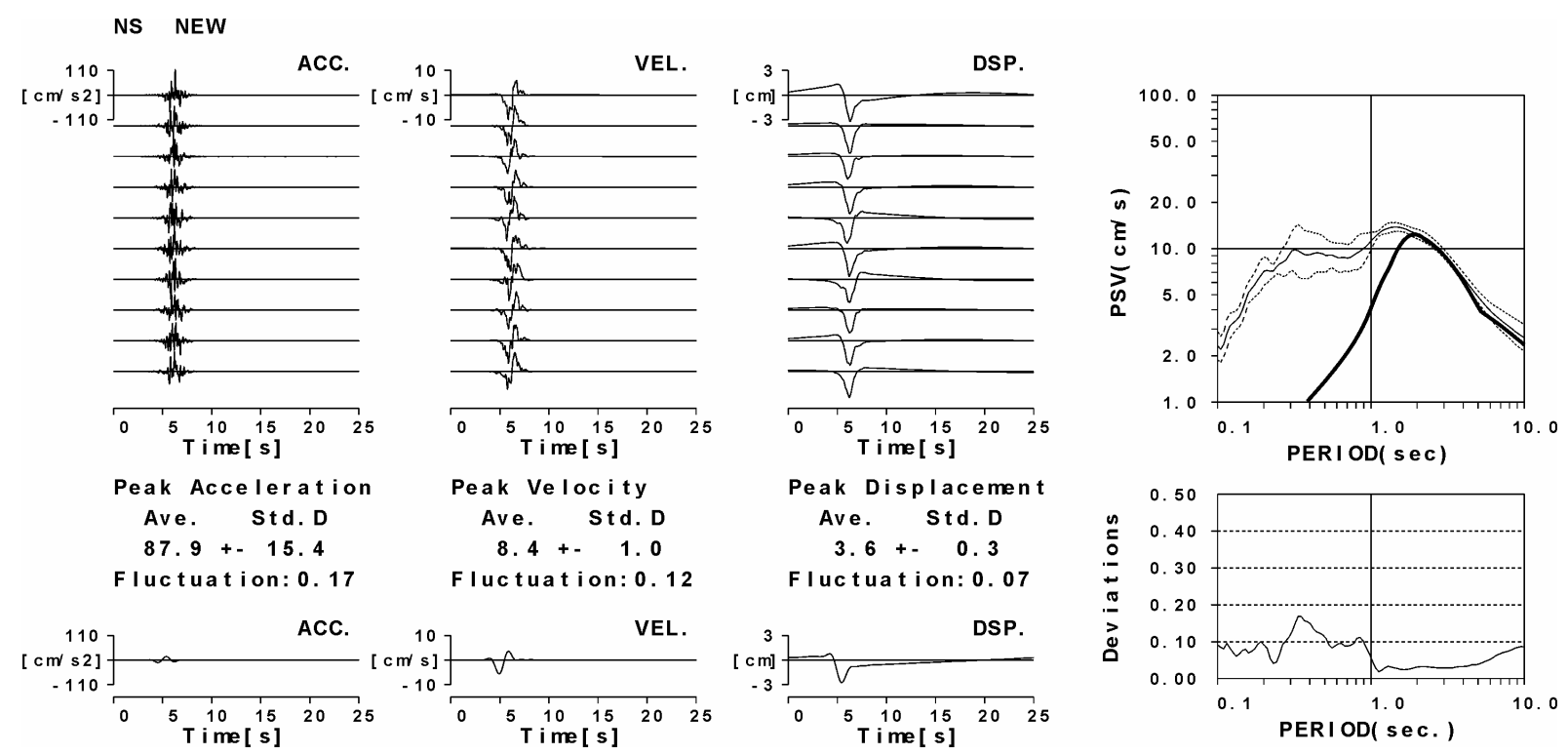

Ave. Std. D

$3.6+-0.3$

F I uctuat ion: 0.07
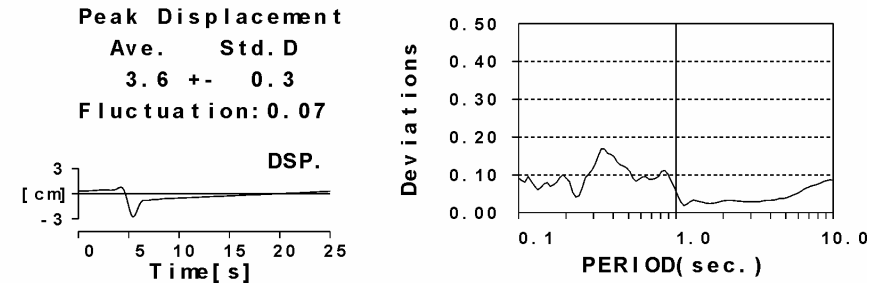

図6(2) サイト 2における計算結果 (提案手法) 
サイト 1 は断層からの SH波成分のみか寄与するため，SH波成分の要素と SV 波成分の要素が渉しない。 そこで,SV波成分の影響か現れるサイト2での計算結果を図6て比較する。図の構成は図 5 と同樣であるが， 10ケースの波形を重ね書きせず，また応答スペクトルの対数標隼偏差值を右下に付記している。従来手法 (図 6(1) ) では速度波形および変位波形が振幅, 位相ともに大きくばらついていることが分かる。振幅のばらつ きは，図1に示したように位相の異なる要素波が干渉したことによるものと考えられる。これを反映して， 長周期帯域でも応答スペクトルの対数標準偏差が 0.15 程度と大きくなっている。ただし，応答スペクトルの 平均值は理論と良く対応している。一方, 提案手法 (图6(2) ) では速度波形およひ変位波形か浱幅・位相と もに良く揃い, 理論波形との対応も良好である。また，応答スペクトルの対数標準偏差も 0.05 程度と安定し ている。SH波成分と SV 波成分の要素波が干渉する条件では，従来手法と提案手法による差か明瞭に現れる。 平成 7 年兵庫県南部地震の神戶市域や 2000 年鳥取県西部地震の強震動生成域はサイト 1 の条件にほぼあては まるため, 手法によらずコヒーレントな長周期波形か計算される。炎の他の条件については，提案手法を用 いることにより，より安定してコヒーレントな長周期波形か計算されることか期待される。

\section{4. 周波数依存型放射特性の効果}

次に，周波数依存型の放射特性を導入した試算例を図 7 に示す。計算条件は図 5(2) に示したサイト 1 と同 樣であるが, 効果を分かり易くするため断層直交方向 (F. Normal) と断層平行方向 (F. Par al l el ) の2成 分で表示している。上 $2 \mathbf{E}^{-}$断層直交方向の統計的計算波形 10 波の重ね書きと理論計算波形 ${ }^{2}$ であり，右側 の疑似速度応答スペクトルは図 $5 ， 6$ と同樣である。下 2段は断層平行方向の計算波形を示すが, 理論では この方向の地震動は現れない。しかし，式( 2)で $\mathrm{f}_{1}=0.5 \mathrm{~Hz}, \mathrm{f}_{2}=5 . \mathrm{OHz}$ (周期で 0.2 2 秒) として周波数依存 型の放射特性を与えているため，短周期成分か強調される加速度では断層直交成分と比較できる振幅で皮形 か計算されている。応答スペクトルで見ても，断層平行方向成分は長周期から短周期に向けて振幅が大きく なり，約 0.2秒で一定振幅となることが分かる。
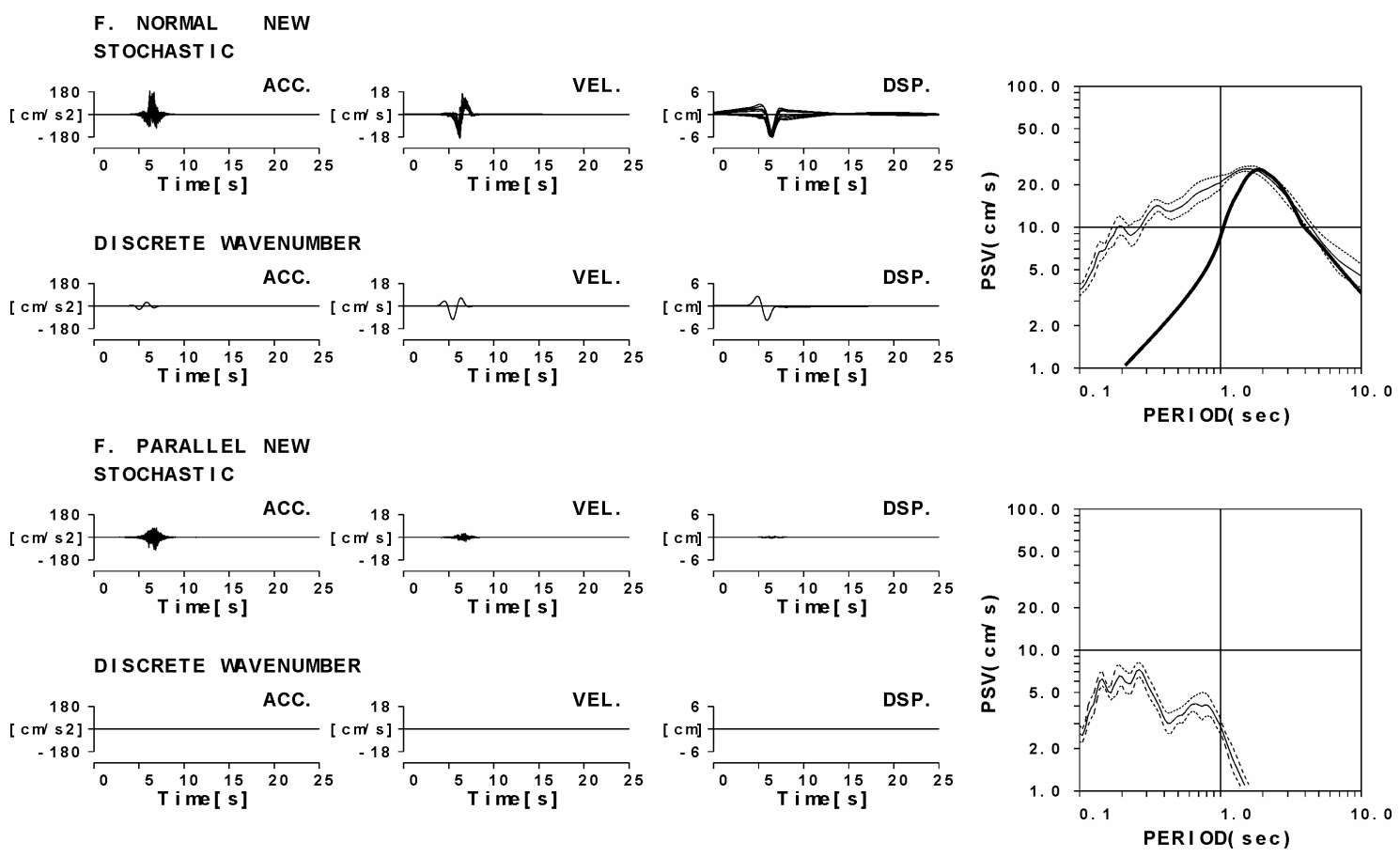

図 7 周波数依存型放射特性を導入したサイト 1 にける計算結果（提案手法） 
このように周波数依存型の放射特性を考慮することにより，短周期では方位特性を持たない統計的なラン ダム波であつたものが長周期になるにつれてコヒーレントでばらつきの小さい波形を示すようになり，現実 の観測記録に見られる定性的な特性か広い周期帯域にわたって合理的に再現されることが分かる。ただし， 周波数依存性の見られる周期帯や光のモデル化など，定量的な条件の設定については，今後の検討課題と言 えよう。特に，ハイブリッド合成の遷移周期帯と放射特性の周波数依存特性の遷移周期帯は, 地震動を確定 量あるいは統計量として扱う際の境界とも密接に関連しており，記録の蓄積を待っての検討が必要である。 本研究て提案する手法を利用することにより，周波数依存型放射特性の遷移周期帯を任意に設定して波形合 成をおこなうことか可能となる。

\section{5. ハイブリッド法への適用例}

提案手法による統計的グリーン関数を用いることにより，断層とサイトの条件にかかわらず長周期帯域ま て理論計算と同樣にコヒーレントな゙波形合成を実施することができる。図８に堆積盆地内の震源断層および サイトで実施した一例を示す。
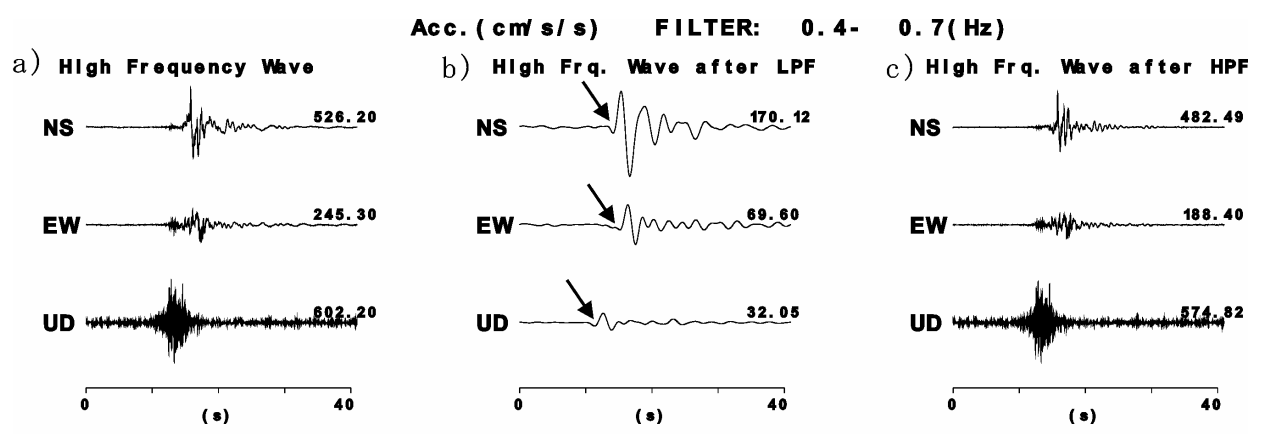

d) Low Frequency wave
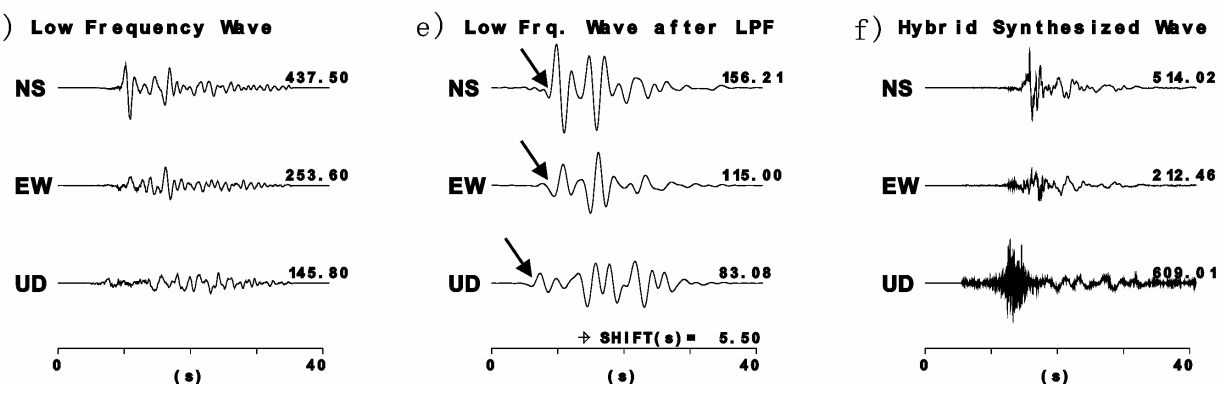

図 8 統計的グリーン関数法と 3 次元差分法のハイブリッド合成例

図の上段は, 提案手法による計算結果 a) を,長周期帯域 b) および短周期帯域 c) に分解したものを示してい る。分解に用いたフィルターはマッチング・フィルター (遷移周波数 0.4-0.7H ) であるため，b) と c) を足 し合わせればa)を再現することかできる。下段のd) は長周期理論計算としての3次元差分法による波形，e) は光れにb) と同じ特性のフィルターを施したものである。ハイブリッド合成は，e)の長周期波形と，c)の短 周期波形を，相互相関関数が最大となるように主要動の時間を揃えて足し合わせることで害行され，弚の結 果f)の広帯域波形が合成されている。このとき，b) と e)の長周期帯域波形同士を比較すると，矢印で示すよ うに，S波主要動については両手法でほほ同樣の波形か計算されていることが分かる。ただし，e)の3次元 差分法では堆積盆地構造による後続波の振幅が大きく，二れは水平成層地盤応答を仮定したb)の統計的グリ 
ーン関数法では表現できていない。このような地震動を取り込めることがハイブリッド法の利点である。短 周期と長周期の計算手法の初期時間の仮定が異なることにより絶対時間に差が見られるが，図 4のハイブリ ッド合成ではb) と e)の相互相関係数が最大となるように波形をずらせて足し合わせをおこなっている (e)の SHFT 量)。これは, b) の統計的グリーン関数法による長周期成分が , 少なくとも S波主要動部て理論波形と 比較できる程度に評価されていることによって可能となっている。

\section{6.おわりに}

主に短周期帯域の地震動評価に用いられる統計的グリーン関数法を長周期帯域まで精度のある地震動とな るように拡張した。提案手法を用いると，統計的グリーン関数を作成する要素地震のコーナー周波数よりも 低周波数でコヒーレントかつ振幅・位相のばらつきの小さい要素地震波を生成することができる。震源断層 ごく近傍の水平成層地盤上のサイトであればほぼ単独で直達波による影響を評価可能ではあるが，盆地表面 波の影響などが大きい場合には理論地震動との差異か顕著となる。光のような場合であっても，拡張した統 計的グリーン関数法と長周期理論地震動を合理的にハイブリッド合成することで, 広い周期帯域て精度の高 い地震動を得ることか可能である。

提案方法では断層モデルと地盤モデルのみから任意地点の地震動を合理的に評価することができ，特に面 的な地震動評価が必要な地震防災上の地震動分布計算に有用であることか期待される。

\section{謝辞}

(財) 地域地盤環境研究所の宮腰研博士には長周期離散化波数法の計算をお願いするとともに，原稿に関す る貴重なコメントを頂いた。また， (株) 大崎総合研究所の壇一男博士，独立行政法人防災科学技術研究所地 震防災フロンティア研究センター川崎ラボラトリーの末冨岩雄博士 , 財) 原子力発電技術機構の大堀道広博士 には計算手法に関する有意義な議論を頂いた。3名の査読者には原稿の改善に有意義な多数の指摘を頂いた。 ここに期して謝意を表する。

\section{参考文献}

1) Kanæe, K, K I ri kura, and A. Pi t ar ka: A techni que for si mul at i ng st r ong gr ound not i on usi ng hybri d Green' s function, Bull. Sei sm Soc. Am, Vol. 88, 1998, pp. 357- 367.

2) Bouchon, M: A si mpl e net hod to cal cul at e Green' s f unct i ons for el ast i c I ayer ed nedi a, Bul I . Sei sm Soc. Am, Vol. 71, 1981, pp. 959971

3) Graves, R. W: Si mul at i ng sei smi c wave propagat i on in 3D el ast i c nedi a usi ng st agger ed- gri d fi ni te differences, Bull. Sei sm Soc. Am, Vol. 86, 1996, pp. 1091- 1106.

4) Boore, D. M: St ochast i c si mul at $i$ on of hi gh-frequency gr ound nøt $i$ ons based on sei snøl ogi cal nodel $s$ of the radi ati on spectra, Bull. Sei sm Soc. Am, Vol. 73, 1983, pp. 1865-1894.

5) 釜江克宏・入倉孝次郎・福知保長: 地域的な震源スケーリンク則を用いた大地震 (M 7 級) のための設計 用地震動予測, 日本建築学会構造系論文集，No. 416，1990，pp. 57-70.

6) Nat sushi ma, S. and T. Sato: Fr equency, di stance, and ti me dependence of radi ati on pattern char acteri stics of strong noti ons, 11th Jpn. Eq. Eng. Sym, 2002, CD ROM 106 .

7) 香川敬生: 断層破壊過程を考慮した模擬地震波の作成, 強震動予測に関する総合的研究, 平成 7 年度科学 研究費補助金 (総合研究 A) 研究成果報告書, 研究課題番号 05302069, 1996, 5362.

8) 大西良広・堀家正則 : 統計的グリーン関数を用いた 3 成分地震動合成法の兵庫県南部地震への適用, 構造 工学論文集, 46B, 2000 , pp. 389 - 398.

9）香川敬生・江尻讓嗣 : 震源断層の破壊過程を考慮した震源近傍地震動の試算,「土構造物の耐震設計に用 いるレベル2地震動を考える」シンポジウム,地盤工学会関西支部， 1998, pp. 1- 6. 
10) Pul i do, N , H Ar ai , H H bi no and T. Kubo: Broadband Ground Not i on Si mul at i on and Danæage Est i mat $\mathrm{i}$ on of the 1999 Kocael i ( Turkey) Ear thquake, Proc, 8th Internati onal Conf er ence on Struct ural Saf ety and Rel i abi l i ty ( I COSSAR' 01), CD ROM, 2001.

11) Br une, J. N : Tect oni c stress and the spectra of sei smic shear waves fromeart hquakes, J. Geophys. Res., Vol. 75, 1970, pp. 4997- 5009.

12) Aki, K and P. G Ri chards: Quanti tati ve Sei snøl ogy, W H Freeman and Co., San Franci sco, Cal i f orni a, 1980.

13) Boor e D. M and J. Boat wri ght: Aver age body- wave radi ati on coeffi ci ent, Bul I. Sei sm Soc. Am, Vol. 74, 1984, pp. 1,615 1, 621

14) Haskel I, N A.: The di sper si on of surf ace waves in moll ti l ayered nedi a, Bull. Sei sm Soc. Am, Vol. 43, 1953, pp. 7-34.

15）入倉孝次郎・香川敬生・関口春子: 経験的グリーン関数を用いた強震動予測方法の改良, 日本地震学会 講演予稿集, 1997年度秋季大会, 1997, B25.

16) I ri kur a, K : Predi cti on of strong accel er at $i$ on not $i$ on usi ng enpi ri cal Green' s f uncti on, Proceedi ng of 7th Japan Soci ety of Civi I Engi neering Earthquake Engi neeri ng Symposi um 1986, pp. 151- 156.

17) Somervi II e, P. G , K I ri kur a, R. Graves, S. Sawada, D. Wal d, N Abr ahanson, Y. I wasaki, T. Kagawa, $\mathrm{N}$ Smith and A. Kowada: Char acteri izing crustal earthquake sl i p nødel s for the predicti on of strong gr ound noti on, Sei snøl ogi cal. Research. Letters., 70, 1999, pp. 59.80.

(受理 : 2003年 7 月 22日)

(掲載決定：2004年 4 月 9日)

\title{
Developing a Stochastic Green's Function Method having more accuracy in long period range to be used in the Hybrid Method
}

\author{
KAGAWA Takao ${ }^{1)}$ \\ 1) Member, Chief Researcher, Geo-Research Institute, Dr. Sci.
}

\begin{abstract}
A hybrid method is developed to simulate near field strong ground motion reasonably in wide period range. As a hybrid method, stochastic Green's function method for short period part and discrete wave-number method for long period part are assumed. It is required that matching period range of the two methods corresponds with the transition range of ground motion between deterministic and stochastic aspects. Because of limitation of structure modeling scale, however, the matching range is usually set to be longer period. The stochastic method proposed in this paper is extended to longer period range than usual one with considering coherent source time function in long period range. Furthermore, frequency dependent radiation pattern and site response of layered media are introduced. Calculated near-filed ground motion by the proposed stochastic method has sufficient accuracy use even for longer period range at a site on basement of flat layered structure.
\end{abstract}

Key Words: Stochastic Green's Function Method, Hybrid Method, Discrete Wave-number Method, Ground Motion 